\title{
A KRASZNOKVAJDAI MIKROTÉRSÉG LAKOSSÁGÁNAK KÖZLEKEDÉSI SZOKÁSAI
}

\author{
(The Traffic Habits of the Population \\ of Microregion Krasznokvajda)
}

\section{LIESZKOVSZKY JÓZSEF PÁL - SZABÓ SZABOLCS}

Kulcsszavak:

Cserehát közlekedésföldrajz térségi elérhetöség falugondnoki szolgálat

Hazánk periférikus térségeiben a rendszerváltozást megelózö évtizedekben - ha meglehetösen szerény mértékben is -, de elfogadhatóak voltak az életköruilmények, és nem voltak kirivóan nagy teriileti különbségek. Azonban ez a csekély anyagi biztonság a rendszervaltozást követö években szerte-foszlott, az ország térszerkezete pedig alapvetöen átalakult. Krasznokvajda mikrotérsége azonban már sokkal korábban, még a trianoni határváltozás következtében süllyedt tartósan abba a depressziós allapotba, amelyböl azóta sem sikerült kilabalnia. A térség tömegközlekedési ellátottsága magán viseli az elmaradottság jegyeit, amelynek feltárása, bemutatása és elemzése képezi a tanulmánynak a tárgyát.

\section{Bevezetö}

A vizsgált térség (Krasznokvajda, Büttős, Kány, Keresztéte, Pamlény, Perecse, Szászfa) a Cserehát északi részén fekszik ${ }^{1}$, és a Cserehát többi településéhez hasonlóan az itt található falvak is alapvetóen völgytalpakra épültek a Rakaca- és a Perecsepatak mentén (Dobány 1999). Krasznokvajda a környezö kisebb lélekszámú, többnyire zsákfalu jellegü települések által alkotott mikrorégió (néprajzi elnevezése: Hétközség) központjaként funkcionál, jóllehet lakossága kevesebb, mint 600 fő (1. térkép). Központi funkcióit mutatja, hogy 3 vegyesbolt, 3 italbolt, háziorvosi rendelö ${ }^{2}$, gyógyszertár, posta ${ }^{3}$, óvoda, általános iskola, mủvelödési ház (benne könyvtár) mủködik a faluban, valamint a mikrorégió munkahelyeinek többsége is itt található (polgármesteri hivatal, körjegyzőség, oktatási és egészségügyi intézmények, magánvállalkozások). Nagyobb bevásárláshoz szükséges kínálattal rendelkezó áruház és szakáruház, valamint szakorvosi és kórházi ellátás, középiskolai és felsőfokú oktatási intézmény azonban már csak a távolabb fekvő városokban (Miskolcon, illetve részben Encsen és Szikszón) érhető el. Az említett városok azonban nehezen megközelíthetők, hiszen nem csak nagy távolságra fekszenek (közúton Encs 25 km, Szikszó 36 km, Miskolc $52 \mathrm{~km}$ távolságra fekszik Krasznokvajdától), hanem kifejezetten rossz a közutak állapota, továbbá alacsony a személygépjármü-ellátottság és ritkán közlekednek a Borsod Volán menetrend szerinti buszjáratai is. Csak megerósíteni tudjuk Bújnóczki Sándornak, Krasznokvajda polgármesterének a megállapítását, mely 
szerint a település olyan feladatokat lát el, amiket általában csak több ezres lélekszámú települések vállalnak fel. Valamelyest segíti a vizsgált települések lakóinak életét a mindenhol jelenlévő falugondnoki szolgálat, a mozgóbolt, az erre is múködő Family Frost, valamint a mozgókönyvtár.

Jelen vizsgálat célja, hogy a Beluszky Pál (1977) által több mint 30 éve Krasznokvajdán és környékén elvégzett vizsgálatok eredményeit értékeljük az elmúlt évtizedek tükrében ${ }^{4}$. Az 1970-es években készuilt felmérés megállapítása szerint a térségben élők közlekedési szokásai az 1950-es években kezdtek megváltozni az ingázás elterjedésével, majd később a közös tanácsok szervezése, valamint a több község határát is egyesítő termelöszövetkezetek létrehozása kỏvetkeztében ${ }^{5}$.

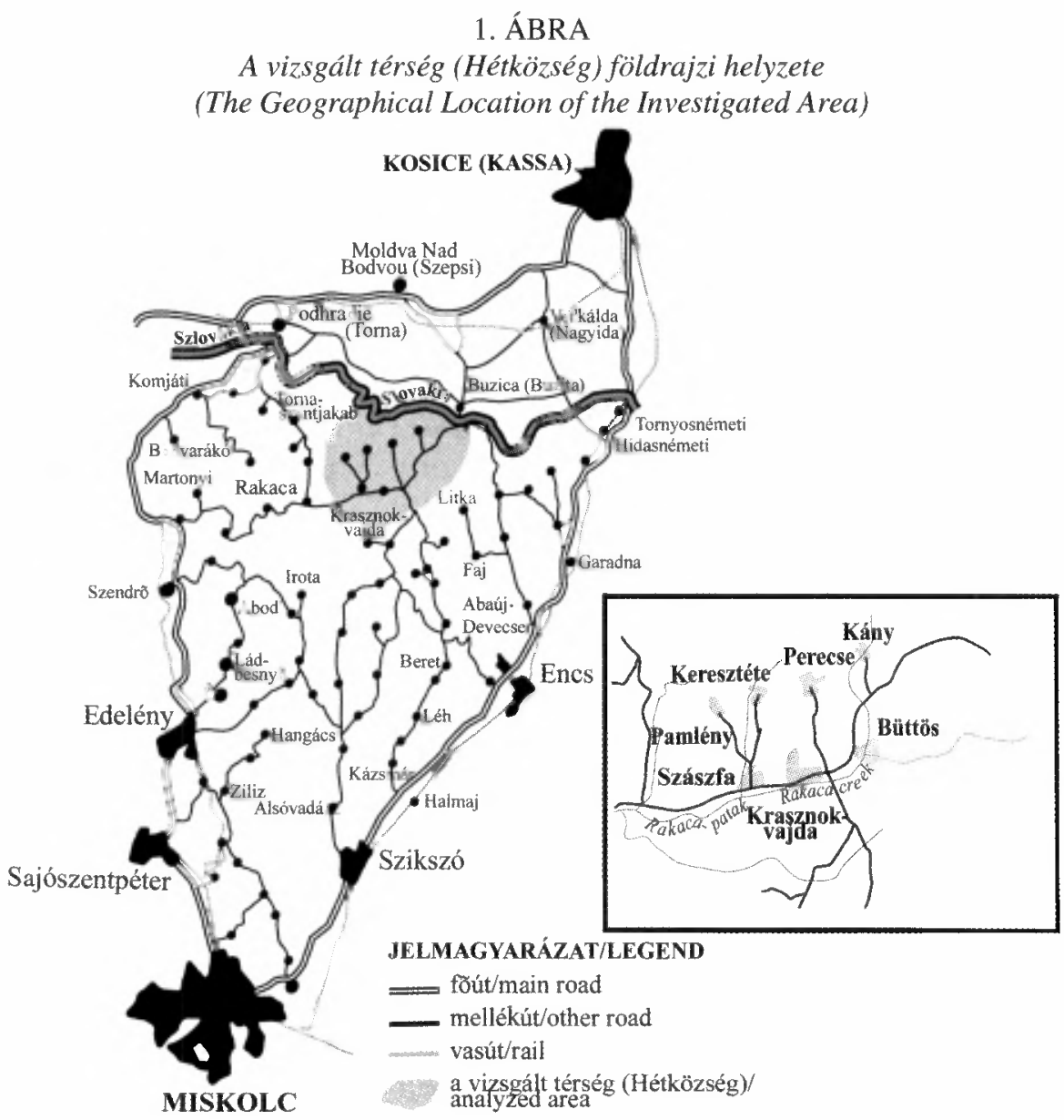

Forrás: Saját szerkesztés.

Ezt megelőzően a térség településhálózata meglehetősen homogén, a lokális intézményhálózat pedig kiépítetlen volt. Rossz volt a térség közlekedési feltártsága, a helyi munkaerőpiac pedig meglehetösen szük, így folyamatos elvándorlás volt 
megfigyelhető. Mindezek következtében az alapfokú hálózati egységek (falukörzetek) nem alakultak ki, voltaképpen társadalmi-gazdasági autarchia jellemezte a környéket ${ }^{6}$. A térség fő jellemezői a következők voltak: a munkahely-koncentrációktól és a városi központoktól való elzártság; egyoldalú mezőgazdasági tevékenység (amelyet kedvezötlen természeti adottságok mellett folytatnak); alacsony színvonalú intézményellátottság; nagyfokú demográfiai erózió; elmaradott művi környezet.

Mindezen jelenségek és folyamatok azonban még elég frissek voltak az 1970-es években, így tanulmányunk célja, hogy megvizsgáljuk az eltelt évtizedek és különösen a rendszerváltozás hatását erre a hátrányos helyzetủ határ menti mikrorégióra, ezen belül is elsősorban arra helyeztük a hangsúlyt, hogy mindezen hatások milyen módon jelentkeznek a közlekedési szokásokban, a térhasználatban.

Terepi munkánk során interjút készítettünk a térség polgármestereivel, valamint a helyi közösségekben fontos szerepet játszó emberekkel, illetve 8 kérdezőbiztos segítségével kérdőíves felméréssel vizsgáltuk a lakosok közlekedési szokásait, valamint a közlekedéssel kapesolatos értékítéletét ${ }^{7}$.

\section{A vizsgált térség rövid társadalmi-gazdasági helyzetértékelése}

\section{Demográfiai adottságok}

A Hétközség a hátrányos helyzetủek közé sorolt encsi kistérséghez tartozik ${ }^{8}$. A népesség száma az ezredfordulóig folyamatosan csökkent, majd ezt követően stabilizálódott (1. táblázat). A népesség száma az 1990. évi népszámlálás szerint már csupán 1410 fö volt a vizsgált térségben (vagyis 1970-hez képes mintegy 800 fővel csökkent!) majd ezt követően néhány településen (elsősorban Krasznokvajdán, valamint Perecsén és Pamlényban) növekedésnek indult. Így öszszességében a térség népességszáma a 2001. évi népszámlálás óta mintegy 35 fövel még növekedett is (1170-ről 1209 före). Mindez alapvetően az egyre erőteljesebb mértékủ betelepülés következménye, jelentỏsebb és tartósabb természetes szaporodás csak Krasznok-vajdán és Pamlényban figyelhetö meg. Bár már itt fontos megjegyeznünk, hogy ez a folyamat semmiképpen nem tủnik fenntarthatónak. Már a 2010-ig történt előrejelzésünk ${ }^{9}$ szerint is inkább csökkenni fog a vizsgált térség össznépessége. A legerőteljesebb fogyás Büttösön prognosztizálható (2010-re a népességszám várhatóan 200 fö alá csökken), de hasonló jelenség figyelhetö meg Szászfán (várható népességszám 150 fö) és Kányban is (a népességszám várhatóan 65 fö alá csökken). A fiatalok egyre inkább elköltöznek, elsősorban a jobb életkörülményeket kínáló nagyvárosokba (Miskolc, Budapest), de van példa olyanra is, aki külföldön próbált szerencsét. Ezzel szemben a bevándorlás meglehetősen hektikusnak nevezhetö, Krasznokvajda esetében például 2005-2006-ban rövid idő alatt költözött be Rakacáról 6-7 család (mintegy 30 fö) (Leskó 2008). 
Lieszkovszky József Pál - Szabó Szabolcs : A krasznokvajdai mikrotérség lakosságának közlekedési szokásai. - Tér és Társadalom 23. évf. 2009/4. 117-135. p.

120 Gyors ténykép

TÉT XXIII. évf. 2009 @ 4

1. TÁBLÁZAT

A térség népességszámának változása, 1980-2010

(The Change of the Population between 1980 and 2010)

\begin{tabular}{lrrrrrr}
\hline & \multicolumn{2}{c}{$\begin{array}{c}\text { Allandó népes- } \\
\text { ség (fö) }\end{array}$} & \multicolumn{2}{c}{$\begin{array}{c}\text { Természetes } \\
\text { szaporodás (fö) }\end{array}$} & \multicolumn{2}{c}{$\begin{array}{c}\text { Vándorlási kïlönbözet } \\
\text { (fö) }\end{array}$} \\
\cline { 2 - 7 } & 1970 & 2006 & $1990-$ & $2001-$ & $1990-$ & $2001-$ \\
& & & 2001 & $2010^{*}$ & 2001 & $2010^{*}$ \\
\hline Büttös & 581 & 243 & -25 & -45 & -7 & -30 \\
Kány & 265 & 72 & -22 & -20 & -9 & -8 \\
Keresztéte & 141 & 33 & -11 & -7 & -8 & 2 \\
Krasznokvajda & 684 & 581 & 24 & 12 & 26 & 57 \\
Pamlény & 264 & 73 & -24 & 8 & -17 & 3 \\
Perecse & 195 & 43 & -16 & -8 & -16 & 30 \\
Szászfa & 334 & 173 & -12 & -35 & -36 & 10 \\
Összesen & 2464 & 1209 & -86 & -95 & -67 & 63 \\
\hline
\end{tabular}

* becslés

Forrás: KSH TSTAR alapján.

A térség településeinek demográfiai problémáit jól mutatja, hogy egyes településeken az átlagos életkor a nyugdijjkorhatár közelében van (Kány, Perecse), fiatalok pedig alig élnek e településeken: például a hivatalosan 72 lakossal rendelkezö Kányon mindössze 1 óvodás, 3 általános iskolás és 1 középiskolás diák van, Perecsén pedig 1 óvodás és 2 középiskolás diák él. Nem véletlen, hogy a környezö települések közösen üzemeltetnek egy általános iskolát Krasznokvajdán, de így is mindössze 140 diák jár az iskolába, 11 településröl ${ }^{10}$. Mivel helyben alig van munkalehetőség (a legtöbb településen az önkormányzat a legnagyobb foglalkoztató), a gazdasági aktivitás még magyarországi viszonylatban is meglehetősen alacsony.

Mindezen folyamatokat terepi tapasztalataink is alátámasztják, sőt még ennél is kedvezőtlenebb tendenciákat mutatnak. A vizsgált települések többségében ma már nagyon sok házat birtokolnak olyanok, akik „csupán” hétvégi házként használják, vagy teljesen lakatlanok. Így az év nagy részében akár egész utcák maradnak üresen (lásd Pamlényban a Kossuth Lajos utcát). Tapasztalhattuk azt is, hogy egyre több külföldi, elsősorban szlovákok, kisebb részben hollandok vásárolnak házat a környéken.

A társadalmi folyamatok kapcsán mindenképpen szót kell ejtenünk a roma népességről, hiszen lélekszámuk a térségben folyamatosan emelkedett az utóbbi évtizedekben, így ma már alig van olyan település a Csereháton, ahol ne élne legalább 1-2 család, de olyan település is van, ahol már joformán csak romák élnek (pl. Csenyéte, lásd Ladányi-Szelényi 2004). Az általunk vizsgált mikrorégióban a 2001. évi népszámlás adatai alapján mintegy $15 \%$ a romák aránya. Legnagyobb arányban Krasznokvajdán, Büttösön és Szászfán élnek. Nem írtak össze romákat Kányban, Perecsén és Büttösön (2. ábra). 
Lieszkovszky József Pál - Szabó Szabolcs : A krasznokvajdai mikrotérség lakosságának közlekedési szokásai. - Tér és Társadalom 23. évf. 2009/4. 117-135. p.

TÉT XXIII. évf. 2009 - 4

Gyors ténykép

\section{2. ÁBRA}

A roma népesség aránya a vizsgált településeken

(The Gypsy Population's Proportion on the Investigated Settlements)

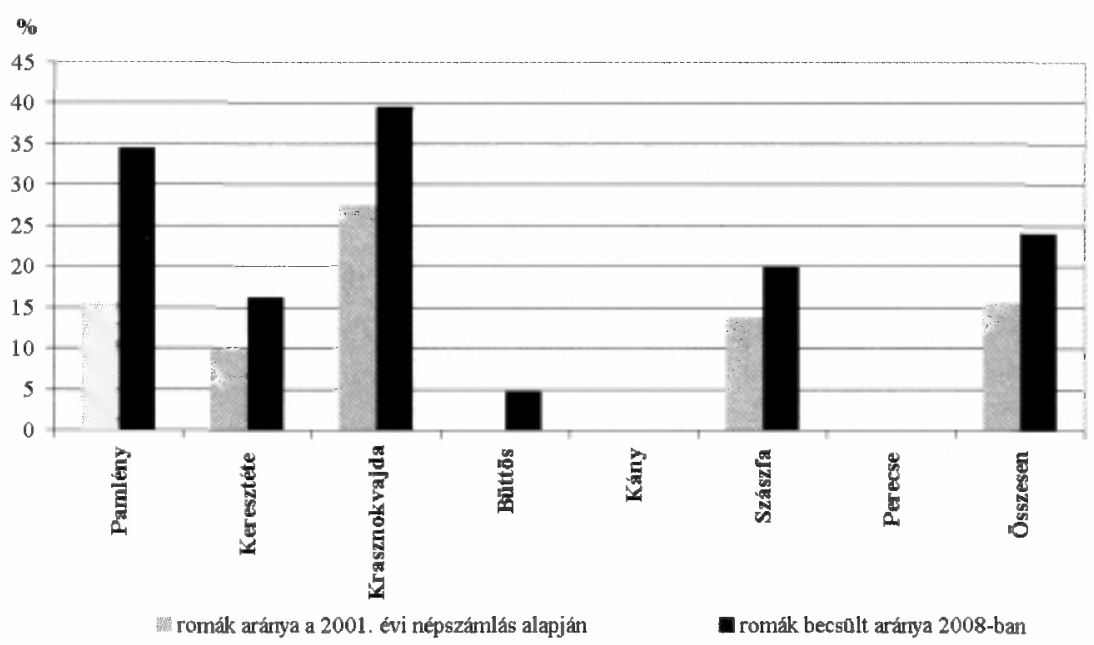

Forrás: KSH 2001. évi népszámlálási adatai és Tirpák László becslése alapján.

A népszámlálás adatainál azonban bizonyosan magasabb a romák aránya, amit mind terepi tapasztalataink, mind a helyiek beszámolói alátámasztanak. A becslés terén a térséget jól ismeró Tirpák László szóbeli közlésére hagyatkozunk, mely alapján a térségben $\mathrm{kb}$. 25\%-ra tehetö a romák aránya, és települési szinten Krasznokvajda esetében már majd' 40\%-os, Pamlényben pedig 35\%-os a részarányuk. Romák csak Kányban és Perecsén nem élnek. Bár a szó hagyományos értelmében vett cigánytelep nincs a vizsgált településeken, de egy-két utcában jellemzően inkább romák laknak (lásd Béke utca Krasznokvajdán).

\section{Foglalkoztatottság}

A rendszerváltozást követő gazdasági átalakulás kedvezôtlenül érintette a térséget, így ma a legnagyobb foglalkoztatónak a települési önkormányzatok számítanak (polgármesteri hivatalok, az önkormányzatok által alkalmazott közhasznú munkások, körjegyzőség, oktatási és egészségügyi intézmények, falugondnoki szolgálat). A vizsgált térségben Krasznokvajdán dolgoznak a legtöbben, hiszen itt mủködik a térségben az egyetlen ovoda és általános iskola, valamint itt van a körjegyzöség is ${ }^{11}$. Az esetenként alig néhány tucat lakóval rendelkezö zsákfalvakban azonban helyben csak a polgármestereknek, a falugondnokoknak, valamint a rotációs rendszerben alkalmazott közhasznú munkásoknak van állása.

A korábbi termelőszövetkezetet (Bástya Tsz), melynek a központja Krasznokvajdán volt, 1998-ban megvette egy, a térségböl elszármazott üzletember ${ }^{12}$, és létrehozta a Magrima '98 Kft-t (időközben több céget is alapítottak a tulajdonosok, de egy érde- 
Lieszkovszky József Pál - Szabó Szabolcs : A krasznokvajdai mikrotérség lakosságának közlekedési szokásai. - Tér és Társadalom 23. évf. 2009/4. 117-135. p.

keltségi körbe tartozó társaságokról van szó). Ezt követően a már korábban is meglévő gyümölcsösök mellett intenzív gyümölcsfa telepítésbe kezdtek, így az elmúlt 10 évben az ültetvények területe megközelítette a 800 hektárt. A fajtaválasztékot úgy állították össze (meggy, alma), hogy júniustól késő őszig folyamatosan teremjenek a fák, így az állandóan alkalmazott, mintegy 70 fö mellett esetenként akár több száz idénymunkást is foglalkoztatnak (részben a vizsgált településekröl, részben más településekről, néha még Dél-Szlovákiából is). A megtermelt gyümölcsöt (többségében almát) különböző alföldi léalma-feldolgozókba szállítják (saját feldolgozója van a cégnek Békéscsabán).

Ezen kívül van még néhány üzlet (fóleg Krasznokvajdán), ahol néhány embert foglalkoztatnak. A gazdasági aktivitás a térségben rendkívül alacsony, mindössze 55 gazdasági szervezet volt 2006-ban, így az ezer före jutó gazdasági szervezetek száma minden településen 100 alatti értéket mutat (2. táblázat). Mindezek következtében a helyi iparüzési adóból jóformán nem származik bevétel.

\section{TÁBLÁZAT}

A vizsgált térség néhány kiemelt mutatószáma

(Some Emphasized Indices of the Investigated Area)

\begin{tabular}{lccc}
\hline & $\begin{array}{c}\text { 1000 före jutó } \\
\text { személygép- } \\
\text { jármüvek száma } \\
\text { 2006 }\end{array}$ & $\begin{array}{c}\text { 1000 före jutó } \\
\text { regisztrált gazda- } \\
\text { sági szervezetek } \\
\text { száma 2006 }\end{array}$ & $\begin{array}{c}\text { Regisztrált állás- } \\
\text { keresök száma (fö) } \\
\text { 2008. l. negyedév }\end{array}$ \\
\hline Büttös & 128 & 96 & 36 \\
Kány & 222 & 152 & 9 \\
Keresztéte & 121 & 2 & 3 \\
Krasznokvajda & 150 & 132 & 79 \\
Pamlény & 137 & 69 & 12 \\
Perecse & 116 & 23 & 1 \\
Szászfa & 87 & 47 & 40 \\
Összesen & 138 & 45 & 180 \\
\hline
\end{tabular}

Forrás: KSH TSTAR alapján.

A 2001. évi népszámlás adatai szerint a vizsgált településeken összesen 202 fó dolgozott napi rendszerességgel, akik közül 58 ingázott, elsősorban a központi fekvésủ Krasznokvajdára (23 fö), Kányra (10 fö) és Miskolcra (6 fö). A többiek jellemzően a környező településeken dolgoztak kisebb számban. Meglepő módon sem Encs, sem Szikszó nem számít jelentös céltelepülésnek az ingázás esetében. Az utóbbi években ráadásul folyamatosan leépültek az elsősorban önellátásra, kis mértékben pedig eladásra termelő családi mikrogazdaságok. Még néhány éve is jelentösebb szarvasmarha állomány volt a térségben (például Krasznokvajdán 80-100 tehén, Kányon 40-50 tehén), de ma már csak néhány háznál tartanak tehenet. Ennek oka alapvetỏen az volt, hogy nem tudták a minőségi tejjel szemben elvárt csíraszámot biztosítani, így az eloóllított tej átvételi ára nagyon alacsony volt. Mindez automatikusan együıt járt azzal, hogy a korábbi legelők elvadultak. Hasonlóképp 
Lieszkovszky József Pál - Szabó Szabolcs : A krasznokvajdai mikrotérség lakosságának közlekedési szokásai. - Tér és Társadalom 23. évf. 2009/4. 117-135. p.

TÉT XXIII. évf. 2009 - 4

Gyors ténykép

123

szorult vissza a sertéstartás, valamint a ház körüli gazdálkodás, illetve a Krasznokvajda határában nagy hagyományokkal rendelkező szőlötermesztés is (családonként jellemzöen pár száz tôke szölớt müveltek korábban).

A munkanélküliség mértékét jól mutatja, hogy a regisztrált munkanélküiliek száma 2008. 1. negyedévében az ÁFSZ (Állami Foglalkoztatási Szolgálat) nyilvántartása szerint 180 fó volt a vizsgált 7 településen (2. táblázat), közülük is 69 fó 180 napnál régebben keresett munkahelyet. A térség lakosságának jelentős hányada részesül különböző szociális támogatásokban. (Csak Kranszokvajdán 97 jövedelempótló támogatásban részesülő ember van ${ }^{13}$.)

\section{A vizsgált térség közlekedési infrastruktúrájának állapota}

A Hétközség közlekedési infrastruktúrája elmaradottnak nevezhető: a térség közúton nehezen elérhető: az utak keskenyek és rossz minőségủ burkolattal rendelkeznek, ráadásul télen sokszor napokig nem járhatóak a hó miatt. A legközelebbi foút is messze van, hiszen a 3. sz. fóútig mintegy 30 kilométert kell utazni. Szlovákia és Magyarország Schengeni Egyezményhez történő csatlakozása annyiban pozitív változásokat eredményezett, hogy a határok szabad átjárhatósága révén Kassa igen közel került, hiszen a város mintegy 40 km-re fekszik Krasznokvajdától, vagyis lényegesen közelebb, mint Miskolc. Így pedig az ottani munkahelyek, valamint a repülötér is könnyen elérhető. Jelenleg Buzita (Buzica) felé lehet átmenni a határon, de a kányi önkormányzat pályázatot adott be a Kány-Reste (Reŝica) közötti földút burkolására. Mintegy 200 millió forintból jó minőségủ utat építenének, így megszünne a település zsákfalu jellege.

A térség közforgalmú közlekedése sem kifejezetten kedvezó (3. táblázat). A buszjáratok ritkán közlekednek (a menetrend szerinti buszközlekedés jellemzését lásd később), a menetrend nehezen áttekinthető, a buszjegy a helyiek jövedelméhez képest kifejezetten drága. Miskolcra egy teljes árú jegy csak oda 900 forint Krasznokvajdáról ${ }^{14}$, ezért az esetek többségében nem is éri meg naponta busszal ingázni ilyen távolságra. Mindezek következtében az itteni élet elengedhetetlen tartozéka a személygépjármü. Ha valakinek van munkahelye, akkor már fenn is tudja tartani, bár a rossz utak miatt a karbantartás nem olcsó. Ennek ellenére a személygépjármủvel való ellátottság meglehetősen alacsony, mindössze 138 személygépjármủ jut 1000 före, ami az országos érték kevesebb, mint fele! (2. táblázat). A közlekedési infrastruktúra elmaradottsága azért fontos tényezö, mert mint már a bevezetőben említettük, Krasznokvajdán müködik egyeduil a térségben óvoda, általános iskola, háziorvos, gyógyszertár, melyek a környező települések lakosságát is kiszolgálják. Az általános iskolába például 140 gyerek jár (fele krasznokvajdai, másik felük a környezö 10 településröl jár be naponta). 
Lieszkovszky József Pál - Szabó Szabolcs : A krasznokvajdai mikrotérség lakosságának

közlekedési szokásai. - Tér és Társadalom 23. évf. 2009/4. 117-135. p.

124 Gyors ténykép

TÉT XXIII. évf. 2009 — 4

3. TÁBLÁZAT

A mikrotérség települései és a fontosabb központok közötti autóbuszos kapcsolat (The Contact by Bus between the Area's Settlements and the More Important Centres)

\begin{tabular}{|c|c|c|c|c|}
\hline \multirow{2}{*}{$\begin{array}{c}\text { Közforgalmú közle- } \\
\text { kedési relációk }\end{array}$} & \multicolumn{4}{|c|}{ Napi járatpár } \\
\hline & $\begin{array}{c}\text { Munkanap } \\
\text { iskolaidóben }\end{array}$ & $\begin{array}{c}\text { Munkanap } \\
\text { tanszünetben }\end{array}$ & Szombat & Vasárnap \\
\hline Miskolc $^{A}-$ Büttös $^{B}$ & - & - & - & $0,5^{\AA}$ \\
\hline Miskolc - Kány & - & - & - & $0,5^{\mathrm{A}}$ \\
\hline $\begin{array}{l}\text { Miskolc - } \\
\text { Keresztéte }\end{array}$ & $0,5^{\mathrm{B}}$ & $0,5^{\mathrm{B}}$ & 1 & - \\
\hline $\begin{array}{l}\text { Miskolc - } \\
\text { Krasznokvajda }\end{array}$ & 4 & 4 & 4 & $4,5^{\mathrm{B}}$ \\
\hline Miskolc - Pamlény & $0,5^{\mathrm{B}}$ & $0,5^{\mathrm{B}}$ & 1 & - \\
\hline Miskolc - Perecse & 1 & 1 & 1 & 1,5 \\
\hline Miskolc - Szászfa & $1,5^{\mathrm{B}}$ & $1,5^{\mathrm{B}}$ & 2 & $1,5^{\mathrm{B}}$ \\
\hline Encs - Büttös & 1 & 1 & 1 & 1 \\
\hline Encs - Kány & 1 & 1 & 1 & 1 \\
\hline Encs - Keresztéte & $0,5^{\mathrm{A}}$ & 1 & - & - \\
\hline $\begin{array}{l}\text { Encs - } \\
\text { Krasznokvajda }\end{array}$ & 3 & 2 & 1 & 1 \\
\hline Encs - Pamlény & $1,5^{\mathrm{A}}$ & - & - & - \\
\hline Encs - Perecse & - & - & - & - \\
\hline Encs - Szászfa & $0,5^{\mathrm{A}}$ & $1,5^{\mathrm{A}}$ & - & - \\
\hline
\end{tabular}

A krasznokvajdai mikrotérség közforgalmú közlekedéssel való ellátottságának problémája persze nem újkeletü, a tömegközlekedési hálózat már az 1960-as években is hasonlóképp gyér volt, mint jelenleg, sőt egyes járatok ${ }^{15}$ szinte „megkövültek"; legalább 50 év óta majdnem ugyanabban az idöpontban indulnak, mint manapság, annak ellenére, hogy azóta többször is gyökeres gazdasági-társadalmi átalakuláson ment át az ország. Úgy látszik, hogy ez a térség tömegközlekedési hálózatát nem rengette meg alapjaiban. Ahogy Beluszky is megemlíti: ,, a falukörzet rendkíviul hátrányos forgalmi helyzete az alacsony járatsürüségben és a járatok idóbeli megoszlásában rejlik", valamint ahogy az ő kutatása idején - mint ahogy jelenleg is „a külvilág számára a falukörzet szinte elérhetetlen” (Beluszky 1977).

Az elmúlt évtizedek folyamán az útirányok többségében nem változtak (MiskolcKrasznokvajda, Miskolc-Perecse, Encs-Kány), azonban megfigyelhetünk ún. „tiszavirág” életú viszonylatokat is, amelyek az épp aktuális igényeket elégítették ki. Ide sorolhatók a bányászjáratok, amelyek az 1970-es évek végén, az 1980-as évek elején léteztek ${ }^{16}, \mathrm{~s}$ egészen Ormosbányáig szállították a bányászokat. A járatok csak a hét utolsó munkanapján és vasárnap közlekedtek egészen Kányig, a többi napokon csak Rakacáig mentek a buszok, mivel a Hétközség távol fekszik az említett bányászvidéktől, s a napi ingázás meglehetősen embert próbáló lett volna. Ugyanettől 
Lieszkovszky József Pál - Szabó Szabolcs : A krasznokvajdai mikrotérség lakosságának közlekedési szokásai. - Tér és Társadalom 23. évf. 2009/4. 117-135. p.

TÉT XXIII. évf. 2009 - 4

Gyors ténykép

125

az időszaktól létezik a mikrotérség (krasznokvajdai végponttal) és a Miskolc-Kassa vasúti fővonal mentén fekvő Halmaj között közlekedő viszonylat is, amely a helyi viszonyokhoz képest meglehetősen sürün közlekedett - napi 4 alkalommal -, s csatlakozást biztosított a Miskolc felé közlekedő vagy onnan érkező vonatokhoz. Meglepö, de még ezzel a vasútra való átszállásos lehetőséggel is gyorsabban el lehetett jutni Miskolcra, mint a meglehetősen rossz állapotú utakon közlekedő közvetlen Krasznokvajda-Miskolc viszonylat használatával. Ennek a kapcsolatnak a járatai azonban az évek folyamán egyre inkább csak bizonyos napokra korlátozódtak (a hét utolsó munkanapja, ill. vasárnapi napokon való közlekedés), majd a kilencvenes évek közepére az utolsó járat - ami egészen Pamlényig közlekedett - is megszünt.

Krasznokvajdáról jelenleg ${ }^{17}$ munkanapokon és szombaton 4 alkalommal nyílik lehetőség közvetlenül eljutni Miskolcra, azonban ezek a járatok meglehetősen aránytalanul oszlanak meg: három járat hajnali 5 óra előtt indul, a negyedik, az utolsó pedig 11.45-kor ${ }^{18}$. Vasárnap öt járat közlekedik, amelyböl a két utolsónak a feladata kifejezetten a kollégista diákok elszállítása. Ellenkező irányban, Miskolcról, a hét minden napján ugyanabban az időpontban indulnak az autóbuszok (délelőtt egy, délután három), amiből az utolsó kettỏ ugyanabban az időpontban indul, de Krasznokvajdáig különböző úton közlekedik ${ }^{19}$. A minden nap azonos időpontban történő indulás sejteti, hogy a menetrend a valós igényeket nem feltétlenül követi.

A mikrotérség többi települése és Miskolc között mindössze napi egy (Szászfa esetén másfél) járatpár jelenti a kapcsolatot, Keresztétéröl és Pamlényröl - szombat kivételével - csak Miskolc irányába van közvetlen járat, Büttös és Kány esetében pedig a kapesolat egy vasárnap délelötti buszban merül ki, amely föleg a rokonlátogatási igényeket elégíti ki.

A kistérségi központba való eljutás még ennél is köruilményesebb: Krasznokvajda és Encs között munkanapokon három közvetlen járat létezik, azonban míg Encsről nagyjából elfogadható időpontokban indulnak, addig Encsre az utolsó busz reggel fél 8 elött elmegy. (Hétvégén csak az egyik járatpár közlekedik, amelyik Büttöst és Kányt is érinti.) Perecse és Encs között egyáltalán nincs kapcsolat. A mikrotérség nyugati települései és Encs városa közötti közvetlen összeköttetés föként az iskolai előadási napokra korlátozódik, azonban meglehetősen aránytalan módon ${ }^{20}$.

A mikrotérség belső közlekedési rendje még az ott élők számára sem teljesen egyértelmủ, a külső érdeklödök számára pedig végképp nem. A munkanapi közlekedési rendben nem csak az iskolai előadási napok és tanszüneti munkanapok vannak megkülönböztetve, hanem eltérő időpontokban indulnak a buszok hétfőn és csiitörtökön (1. blokk), valamint kedden, szerdán és pénteken (2. blokk), ami sokszor csak néhány perces különbséget jelent ${ }^{21}$. A mikrokörzet belső közlekedését lebonyolító járatok egy része a már említett Encs és Miskolc relációjú járatok, csak a Hétközségen belüli végcélokkal tanítási napokon van busz: reggel Pamlénytöl Kányig közlekedik, majd vissza Krasznokvajdára, ill. délután egy hasonló kezdôpontú busz, de az nem Kánynál, hanem már Büttösnél visszafordul Krasznokvajda felé. 


\section{A közforgalmú közlekedés hiányosságainak egy kezelési módja: a falugondnoki szolgálat}

Az aprófalvas térségek lakosságának ellátásában már Magyarországon is fontos szerepe van a falugondnoki szolgáltatásnak, melynek kialakulása még az 1980-as évekre nyúlik vissza. Ekkor civil kezdeményezésre a Népjóléti Minisztérium támogatásával Borsod-Abaúj-Zemplén megyében indult be a program. A falugondnokokról már az 1993. évi III. törvény, valamint annak 1996. évi módosítása is rendelkezett, majd 1998-tól támogatják az alacsony lélekszámú telepuilések esetében a jármúvek beszerzését, valamint azok üzemeltetését, normatív alapú támogatás formájában. A jármủveket már az eredeti koncepció szerint sem csak szociális célra lehetett használni, hanem egyéb (piaci alapú) személyszállításra is bérbe lehet venni. A Szociális és Családügyi Minisztérium 1/2000 (1.7.) rendeletének meghatározása szerint: „A falugondnoki szolgáltatás célja az aprófalvak (és a külterületi lakott helyek) intézményhiányból eredö települési hátrányainak enyhítése, az alapvetö szükségletek kielégitését segítö szolgáltatásokhoz, közszolgáltatáshoz, egyes alapellátásokhoz való hozzájutás biztosítása."

Az ezredfordulón már összesen mintegy 800 településen volt falugondnoki, valamint ennek egy speciális változata, az ún. tanyagondnoki rendszer (Szanyi-Kemény 2003). Jelenleg mintegy 1000 településen létezik a szolgáltatás, (714 falugondnoki és 224 tanyagondnoki szolgáltatás) (Kostyál 2008), ami az utóbbi években is folyamatosan fejlödött, és ma már az ÚMVP (Új Magyarország Vidékfejlesztési Program) keretében is lehet pályázni falugondnoki és tanyagondnoki buszok vásárlására, melyhez már önerỏ sem szuikséges. Az általunk vizsgált térségben minden település nyert már korábbi pályázatokon pénzt a falugondnoki mikrobusz (közösségi busz) vásárlására, mely révén jellemzően mikrobuszt (8-9 fỏs jármü) vettek. Krasznokvajdán azonban már 3 jármü ${ }^{22}$ is üzemel. Ezen kívül fontos megemlíteni, hogy a települések a falugondnok foglalkoztatására is kapnak támogatást. A buszjáratok hiányát úgy pótolják, hogy a falugondnoki mikrobuszok figyelembe veszik a környező települések buszjáratait (foóleg Krasznokvajdán és Encsen van átszállási lehetöség), és ahhoz csatlakozva jönnek-mennek. Mivel a krasznokvajdai iskolába járnak a környezó telepuilések tanulói, ezért az ő napi utaztatásukban is fontos szerepet játszik a falugondnoki szolgálat.

A kisebb telepuiléseken minimális összegért többnyire vállalnak költségtérítéses utat is (ilyenkor jellemzően a benzinköltséget kell csak megtéríteni az utasoknak). Így pl. Kányról Encs 2000, Miskolc 3000 forintért elérhető (a mikrobusz kibérlése kerül ennyibe, vagyis fejenként a buszjegy árának töredékébe került az út). Krasznokvajdáról a kisbusz kibérlése 7000 forint egy miskolci útra. Ráadásul nincs kötött menetrend, és jellemzően háztól-házig szállítást végeznek. Amikor a falugondnoki mikrobuszt kibérli valaki (vagy valakik), akkor ezen idószakban a többi (hagyományos) feladatát egy környező telepuilés falugondnoka látja el, helyettesítéssel. Az itt élők vásárlási szokásaira egyébként is jellemző, hogy havonta egyszer-kétszer mennek az 
Lieszkovszky József Pál - Szabó Szabolcs : A krasznokvajdai mikrotérség lakosságának közlekedési szokásai. - Tér és Társadalom 23. évf. 2009/4. 117-135. p.

TÉT XXIII. évf. 2009 " 4

Gyors ténykép

127

emberek nagyobb bevásárlásra (néhány dolgot ma már célszerübb és olcsóbb Szlovákiában beszerezni - pl. a gázpalack cseréje). Különösen nagy jelentősége van ennek a beiskolázás időszakában, amikor a gyerekeknek kell a szükséges felszerelést megvásárolniuk. Ilyenkor jellemzöen miskolci hipermarketekbe járnak.

Ráadásul kb. hetente járnak tankolni a mikrobusszal (az APEH elöírásai miatt nem tárolhatnak benzint), és ekkor ingyen elvisznek embereket Encsre bevásárolni, ahol a legközelebbi benzinkút található. A már nehezebben kimozduló idősebb embereknek lista alapján be is vásárolnak, valamint délben ebédet hordanak Krasznokvajdáról a szomszédos településekre a falugondnokok ${ }^{23}$. Munkájuk jelentôs részét teszi ki a betegek szállítása (elsősorban a krasznokvajdai háziorvosi rendelőbe), hétköznap reggel és délután az iskolások és óvodások szállítása (van, ahol reggel van megfelelö buszjárat, csak visszafelé nem tudnak utazni). Néhány esetben még munkavállalókat (pl. a körjegyzóségben dolgozókat) is szállítanak. Iskolai tanítási időszakban jellemző az is, hogy a közép- vagy felsőfokú tanintézményben tanulókat vasárnap elviszik Encsre, Szikszóra vagy Miskolcra, ahonnan menetrend szerinti busszal vagy vonattal tudnak tovább utazni. Speciális feladatot jelent, ha hirtelen rosszullét esetén kell valakit az encsi ügyeletre beszállítani. Mivel a mentöre sokszor órákat kell várni, ezért arra is gyakran van példa, hogy riasztják a mentöt, majd félúton találkoznak (jóllehet egészségügyi szakszemélyzet nincs a buszokon).

A szolgáltatás lakossági megítélése elég vegyes (lásd a kérdőívek kiértékelésénél), azonban ennek ellenére elmondható, hogy a falugondnoki szolgálat sokrétű szolgáltatást nyújt a térségben élőknek, és ma már hozzátartozik az itt élők hétköznapjaihoz. Esetenként más megoldás is szóba jöhet az alternatív közlekedési lehetöségek közül. Egyfajta iránytaxiként müködő rendszerben a Magrima '98 Kft.-ben dolgozó néhány kányi lakost egy ott dolgozó és Szalaszendről naponta bejáró foglalkoztatott szállítja Krasznokvajdára saját autójával. Ezen kívül - egyelöre elsősorban a roma lakosok körében - a valódi iránytaxi szolgáltatás is megfigyelhetô (az iránytaxi szolgáltatásról lásd Szabó 2006). Egy Krasznokvajda-Encs viszonylat a szokásjog alapján 3000-3500 forintba kerül (Leskó 2008).

\section{Közlekedési szokások és az aktivitási tér sajátosságai a vizsgált térségben}

\section{A minta összetétele}

A kutatás során a Hétközség 14 éven felüli lakóit kérdeztük meg, összesen 285 föt. Az életkoruk függvényében a válaszadókat három korcsoportra osztottuk: 14-25 év közöttiek ( $\mathrm{N}=58), 26-59$ év közöttiek $(\mathrm{N}=128)$ és 60 év felettiek $(\mathrm{N}=99)^{24}$. Legnagyobb arányban a 25-69 év közöttiek reprezentálták magukat (45\%), azt követte a 60-89 év közöttiek csoportja (35\%), s legkevesebben a 25 év alattiak szerepeltek (20\%). Az összes megkérdezett 43\%-a férfi, viszont a 60 évnél idősebbek körében a 
nök szerepelnek jóval nagyobb arányban (68\%). Települési bontásban ettől eltérő képet kapunk; az első, a fiatalok kategóriájában a 4 törpefaluban (Kány, Keresztéte, Pamlény, Perecse) csak 1-2 fó szerepel (3-13\%), s ezzel párhuzamosan az elöbbi két faluban az időskorú válaszadók aránya 2/3-ad feletti volt, míg Pamlényben és Perecsén $45 \%$ alatt maradt. A további településeken a fiatalkorú válaszadók aránya 16-31\% közötti. A középkorúak aránya átlagosan 40-55\% között mozgott (kivétel Kány és Keresztéte, ahol 30\% alatt). Az időskoníak aránya Krasznokvajdán volt a legalacsonyabb (21\%). A válaszadók településenkénti korcsoportbeli arányait öszszehasonlítva a települési népszámlálási adatokkal megállapíthatjuk, hogy korra nézve a vizsgálatunk reprezentatívnak bizonyult.

A válaszadók foglalkozását nézve a legnagyobb arányban a nyugdíjasok képviseltették magukat $(\mathrm{N}=101,35 \%)$, öket követi a fizikai munkások csoportja $(\mathrm{N}=43$, 15\%). A tanulók és a munkanélküliek aránya szinte megegyezik (14-14\%), ami igencsak elgondolkodtató. Legalacsonyabb számban a szellemi munkakörben dolgozók vannak. A különböző szociális juttatásokon élők (GYES, GYED, rokkantsági nyugdíj) 9\%-ban képviseltették magukat a kutatásban. A falukörzet hátrányos helyzetét ismerve nem meglepö, ha külön csoportban szerepelnek a közhasznú munkások, mivel számuk nem elhanyagolható ( $\mathrm{N}=18,6,3 \%)$ (3. ábra).

\section{3. ÁBRA}

A válaszadók foglalkozás szerinti megoszlása

(The Respondents' Distribution According to their Occupation)

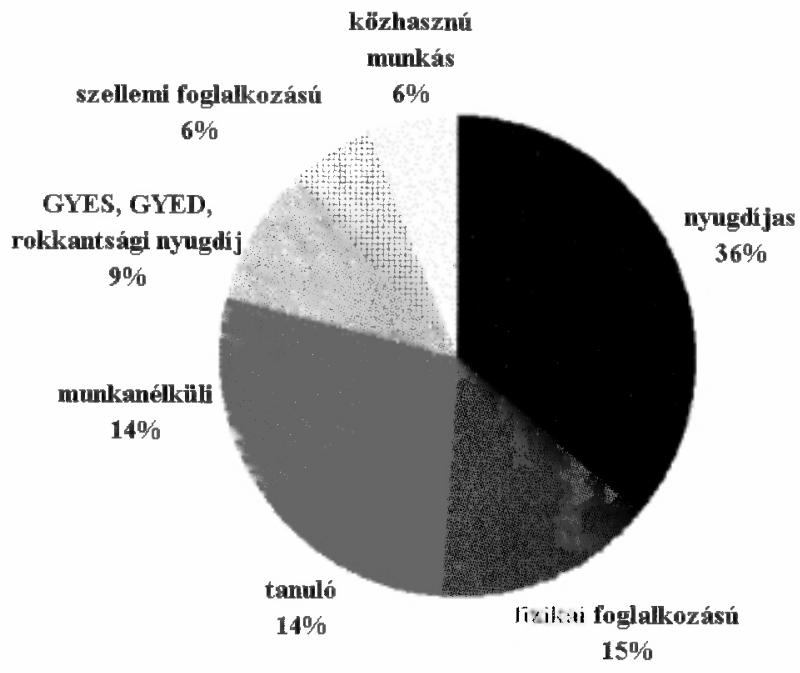

Forrás: Saját szerkesztés.

A mikrokörzet falvait nézve a nyugdíjasok - mint a legmarkánsabb csoport - aránya nem meglepő, hogy a legkisebb lélekszámú faluban, Keresztétén a legmagasabb (67\%). A többségi lakosság Kányban (60\%) és Perecsén (53\%) is nyugdíjas. A három nagyobb 
Lieszkovszky József Pál - Szabó Szabolcs : A krasznokvajdai mikrotérség lakosságának közlekedési szokásai. - Tér és Társadalom 23. évf. 2009/4. 117-135. p.

TÉT XXIII. évf. 2009 @ 4

Gyors ténykép

129

településen, Krasznokvajdán, Büttösön és Szászfán viszont 30\% alatt marad a nyugdijasok aránya. A válaszadók körében a tanulók aránya Büttösön volt a legmagasabb (29\%), a többi településen $15 \%$ alatt volt; a fizikai foglalkoztatottak pedig Krasznokvajdán képviseltetik magukat legnagyobb számban és arányban egyaránt (26\%).

\section{A megkérdezettek közlekedési szokásai}

A közlekedési eszközök használatának gyakorisága kérdéskörben a helyközi autóbusszal, a falugondnoki busszal, személygépkocsival és kerékpárral való közlekedés gyakoriságát vizsgáltuk. A válaszadók mindössze 5,3\%-a használta napi rendszerességgel a helyközi autóbuszokat; a naponta közlekedők ( $\mathrm{N}=15)$ közel fele (46\%) büttösi lakos, negyede pedig kányi. Pamlényen, Perecsén és Keresztétén nincs olyan személy, aki napi rendszerességgel utazna busszal. Hetente többször 21 fö használja (7,4\%); akiknek közel fele krasznokvajdai lakos. A megkérdezettek 17\%-a havonta használja csak a helyközi autóbuszjáratokat, s legtöbben a havinál ritkább, de azért az elvétve használók csoportjába tartoznak; ami a telepuilések lakóinak 30\%-át jelenti. A mikrotérség 14 éven felüli lakóinak majdnem a negyede egyáltalán nem használja a helyközi autóbusz nyújtotta szolgáltatásokat, ennek aránya igen tág határok között mozog, a perecseiek 60\%-a áll szemben a szászfaiak 11\%-ával.

A falugondnoki buszt a válaszadók hasonlóan alacsony aránya használja napi szinten ( $\mathrm{N}=16,5,6 \%)$, amely egyharmad-egyharmad arányban a kányi és a büttösi lakosok között oszlik meg. Havonta a válaszadók 20\%-a használja; a büttösi, szászfai és pamlényi lakosok negyede, a többi településen ennél alacsonyabb arányban. A legnagyobb csoportot a havi rendszerességnél ritkább használók alkotják ( $\mathrm{N}=55$, $19,3 \%$ ) - a keresztétei és a perecsei lakosok kivételével $25 \%$ vagy annál nagyobb arányban (pamlényiek fele). Egyáltalán nem utazik falugondnoki busszal a válaszadók közel egynegyede ( $\mathrm{N}=70,24,6 \%)$.

Személygépkocsival napi rendszerességgel jóval többen utaznak, mint a helyközi autóbusszal ( $\mathrm{N}=29,10 \%)$. Minden harmadik keresztétei válaszadó naponta használja a személygépkocsit, a többi településen $15 \%$ alatti ez az arány. A naponta utazók táborát egyébként a krasznokvajdaiak alkotják legnagyobb számban $(\mathrm{N}=11,38 \%)$. Mind a hetente többször, mind heti rendszerességgel kevesebb válaszadó használja az autót, mint naponta - jelezve, hogy a személygépkocsi főképp napi használatra szánt közlekedési eszköz. A ritkábban, mint havonta lehetőséget a válaszadók 22\%-a jelölte meg, itt települési szinten föleg a szászfaiakat $(\mathrm{N}=18,32 \%)$ és a kányiakat $(\mathrm{N}=8,27 \%)$ érdemes megemlíteni. Egyáltalán nem használja a személygépkocsit a pamlényiek háromnegyede (!) (N=13,65\%), valamint az elöbbi két település (Kány és Szászfa) lakóinak közel a fele.

A mikrotérség lakói számára a legfontosabb napi közlekedési eszköz a kerékpár, ez nem csak a kutatásból derül ki, hanem a terepmunka során is megtapasztaltuk. A válaszadók $26 \%$-a $(\mathrm{N}=74)$ napi rendszerességgel biciklizik, azonban telepuilési szinten ezen esetben nagy eltéréseket tapasztalhatunk: amíg a krasznokvajdaiak és 
büttösiek több mint harmada naponta kerékpározik, addig egyetlen egy keresztétei és perecsei lakost sem találtunk, aki ezt hasonló rendszerességgel tenné. Ennek föként az az oka, hogy Perecsén és Keresztétén semmilyen alapszolgáltatás sincs a faluban, hiszen a köz- és egyéb szolgáltatások más településen találhatók, amelyek elérése a túlnyomóan idős lakosság számára nem kerékpárral, hanem falugondnoki busszal történik. Heti, kétheti és havi rendszerességgel használók aránya elenyészö; ritkábban, mint havonta átlagosan a települési lakosok 10\%-a használja. Annak ellenére, hogy a legfontosabb napi közlekedési eszköz a bicikli, ebben a csoportban található a legnagyobb „sohasem használók” aránya - 46\%. A települési eloszlás itt is tarka - a legalacsonyabb Kányban (40\%), a legmagasabb pedig Kereszététén (84\%).

A válaszadók foglalkoztatási csoportjairól a fejezet elején már szót ejtettünk, az alábbiakban a munkával rendelkezỏ lakosság kerül elemzésre. A válaszadóknak mindössze egynegyede $(\mathrm{N}=73)$ munkavállaló, akik közel kétharmada $(\mathrm{N}=48)$ a lakóhelyén dolgozik. (Minden településen létezik egy-két fö, aki helyben dolgozik, a legtöbb Krasznokvajdán, 33 személy.) A fennmaradó mindössze 25 (!) fö - a munkavállaló válaszadók $36 \%$ - nem a lakóhelyén dolgozik. A térségen kívülre csak öten ingáznak (ketten Encsre, hárman Miskolcra - mindannyian krasznokvajdai lakosok), 6 személy munkavégzésének helyszíne változó, ill. nem településhez köthetö (építőipari munkás különböző településeken vagy gyümölcsszedỏ), azaz csak 14 fö vesz részt a munkavállalási célú településközi ingázásban a mikrotérségen belül, akik munkahelye jobbára Krasznokvajdán található. (Megjegyzésként: az előbb említett 14 fö a munkavállaló válaszadóknak mindössze 18\%-a.)

A munkahelyre való eljutás során a leginkább használt közlekedési eszköz a helyközi autóbusz, a válaszadók közel 60\%-ának közlekedési eszköze (pl. a büttösiek és a szászfai lakosok több mint háromnegyedének). Személygépkocsit csak minden ötödik ember használ, döntően a krasznokvajdaiak. Falugondnoki busszal vagy a helyközi autóbusz és a falugondnoki busz kombinációjával csak elvétve találkoztunk. Érdekességként megemlíthető, hogy Keresztétén és Pamlényen a kérdezőbiztosaink nem találtak olyan személyt, aki az adott településről eljárna dolgozni, ill. Perecséről csak egy hölgy jár el dolgozni, ö ezt az utat falugondnoki busszal teszi meg. Érthetö, hogy magasabb a helyközi közlekedést használók aránya a két „nagyobb faluban”, mint Krasznokvajdán, hiszen ezekről a településekröl az ingázók Krasznokvajdára mennek, míg a központi településről eljárók föként személygépkocsit használnak.

A buszjáratok menetrendje a válaszadók 1/3-da számára megfelelö, ez az arány valójában magasabb, - ismerve a közforgalmú közlekedés helyi viszonyait -, mint amit az előzetes feltételezéseink során vártunk (4. ábra). Települési szinten vizsgálva kiugrik a keresztétei lakosok válasza, ahol majdnem mindenki számára elfogadható a meglévő menetrend. E mögött feltehetően az áll, hogy a jobbára idős lakosok számára sok esetben mindegy, hogy mikor közlekedik a busz, mivel nem vagy igen ritkán használják. Főként ott és azon esetben jelentkezik - érthetỏ okokból - kardinális problémaként a hiányos buszközlekedés, ahol jobban rá vannak szorulva lakosok a közforgalmú közlekedés használatára. A válaszadók szerint a menetrend leg- 
Lieszkovszky József Pál - Szabó Szabolcs : A krasznokvajdai mikrotérség lakosságának közlekedési szokásai. - Tér és Társadalom 23. évf. 2009/4. 117-135. p.

TÉT XXIII. évf. 2009 - 4

Gyors ténykép

nagyobb problémája - amellett, hogy meglehetősen kevés busz érinti a térséget föként az, hogy napközben nem megoldott a nagyobb központokból való visszaút (Encsről vagy Miskolcról), Krasznokvajdáról délután nincs közvetlen busz Miskolcra, ill. nyári időszakban az iskolabuszok nem közlekednek, pedig lenne rá igény - ahogy a kányi lakosok többsége ezt állította.

A falugondnoki szolgálat megítélése alapvetően pozitív (4. ábra), bár az egyes települések esetében megfigyelhetünk némi különbséget e téren.

\section{4. ÁBRA}

A falugondnoki szolgálat, valamint a Borsod Volán Zrt. szolgáltatásának lakossági megítélése a vizsgált mikrorégióban

(The Population Judgement of the Village Assignee Service and Borsod Volán Ltd. in the Investigated Microregion)

A menetrend szerint közlekedő buszok menetrendjének megítélése

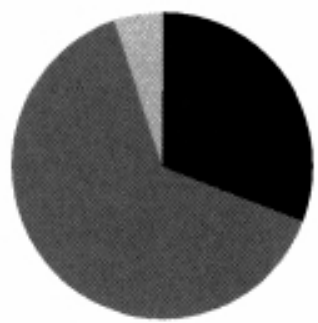

- megfelelö
A falugondnoki szolgálat közlekedési szolgáltatásainak megítélése

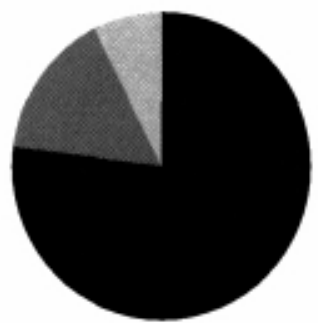

I megfelelő

Forrás: Saját szerkesztés.

A négy törpefaluban szinte mindenki teljesen elégedett a falugondnoki szolgálat$\mathrm{tal}^{25}$, a többi három településen azonban ettől eltérő a helyzet, a legszélsőségesebb esetben, Szászfán a válaszadók 30\%-ának problémája volt vele. Itt az elégedetlenség abból fakad, hogy nem mindenkit szállít el a „falubusz”, szerintük inkább családi autóként üzemel, mint közösségi jármüként. Az elégedetlen krasznokvajdaiak szerint fóként pénzért szállít, azaz olyan esetben is elkér pénzt, amikor nem lenne szabad; a büttösiek pedig a megbízhatatlanságát hozták fel, ami részint azt jelenti, hogy a megbeszélt helyen és időben nem volt ott, illetve korábban elindult a bevásárló körútra. Mindhárom település esetében felfedezni véltünk etnikai törésvonalakat a falugondnoki szolgálattal való elégedettség-elégedetlenség kapcsán, azaz a roma válaszadók voltak többségben az elégedetlenek táborában. Ennek a problémának a részletesebb feltárása azonban nem célja a jelen tanulmánynak.

\section{A fontosabb áruk és szolgáltatások elérhetösége}

A háziorvosi szolgáltatást szinte mindenki Krasznokvajdán veszi igénybe, az ahhoz való eljutás a helybelieknek számára jobbára gyalog (46\%) történik, míg a többi 
településröl leginkább falugondnoki busszal - Kány (90\%), Pamlény (85\%), illetve kombinált módon. A helyközi autóbuszt föleg azok veszik igénybe, akiknek a háziorvosa nem Krasznokvajdán található, hanem pl. a mikrotérségen kívuil eső elözö lakhelyükön.

A szakositott orvosi ellátásra Encsen, Miskolcon és Szikszón van lehetöség a Hétközség lakói számára; nagyobb hányaduk (42\%) mindhárom központot fel szokta keresni, csak Szikszóra a válaszadók 33\%-a jár; Miskolcra nagyobb arányban járnak a krasznokvajdaiak, Encsre pedig a perecseiek. A rendelöintézetek megközelítésének módja változatosabb, mint a háziorvosi szolgálaté: ebben az esetben a helyközi autóbusznak jut a legnagyobb szerep (46\%), második helyen viszont a személygépkocsi szerepel (27\%), s csak ezt követi a falugondnoki szolgálat (14\%). Természetesen van olyan település, ahol a helyközi autóbusz részaránya jóval magasabb (Szászfa 71\%), vagy egyáltalán nem is használják erre a célra, mint Keresztétén. Az autóhasználat eléggé homogén, viszont a falugondnoki szolgálat települési részaránya meglehetősen tág határok között mozog; amíg Krasznokvajdán és Pamlényben csak 6-7\%, addig Perecsén és Keresztétén 50\% felett szerepel.

A hivatalos ügyek intézésére meglehetösen sok helyen kerül sor. Egyrészt a körjegyzőségeken (Gagyvendégi, Krasznokvajda, Szászfa), valamint a kistérségközpontban (Encs) kerül sor. A lakosok többsége Encsre jár, a kányiak járnak még nagyobb arányban Krasznokvajdára és a szászfaiak helyben intézik ügyeiket (51\%). Az eljutásban viszont arányosabban megoszlanak a fontosabb lehetöségek (helyközi autóbusz $34 \%$, autó $24 \%$, falugondnoki $13 \%$ ), mint az előző esetekben, s egyéb lehetỏségek is felmerülnek (gyalog és a kombinált forma). A kányiak és a keresztéteiek főként és újra a falugondnoki szolgálatot hívják segítségül, míg a pamlényiek, a büttösiek és a vajdaiak inkább helyközi autóbusszal utaznak (40-45\%), utóbbi településen a személygépkocsi-használat is számottevő ( $28 \%$ ).

Az élelmiszer-vásárlás során találkoztunk a legsokrétübb lehetőségekkel; nem csak a három nagyobb mikortérségi település, a kistérségközpont (Encs), valamint Szikszó és Miskolc merült fel lehetöségként, hanem ezek kombinációi, valamint a nem helyhez kötött formák: a mozgóbolt - ami föként a kányiak és a perecseiek számára népszerü -, valamint a gyermek részéröl történỏ bevásárlás. A válaszadók $38 \%$-a két vagy több helyen is be szokott vásárolni, jellemzỏen a kisebb bevásárlásokat helyben (helyi bolt, mozgóbolt), a nagyobb élelmiszer-bevásárlásokat viszont Encsen vagy Miskolcon ejtik meg. Általánosságban a bevásárlás helyszínéhez való eljutás során egyik közlekedési eszköz sincs preferálva. Érdekes, hogy a szászfaiak és a büttösiek többsége helyben vásárol, míg a krasznokvajdaiak és a további négy törpefalu lakossága elónyben részesíti a távolabbi bevásárlásokat is. A magyarázat abban rejlik, hogy a legkisebb falvakban semmilyen bolt nincs (ugyan a mozgóboltos hetente többször érkezik, sőt van külön zöldséges is - ezt egy perecsei lakostól hallottuk), így az a lehetöség sem áll fenn, hogy napközben bármikor apróbb fogyasztási cikkekért „,beugorjanak a boltba”. Így ha bármilyen bevásárlást megejtenek, akkor azt ritkábban teszik meg, nagyobb tételben vásárolnak, ezáltal szélesebb termékskálával rendelkezö boltokat - jellemzỏen kisebb szupermarketeket vagy hipermarketeket 
(Tesco, Auchan) - keresnek fel, amelyek legközelebb Miskolcon és Encsen találhatók. Ahogy a perecsei polgármester-asszony elmondta, mindenki spejzol a faluban, $\mathrm{s}$ amiböl lehet, több hónapra elöre vásárolnak. Mivel Szászfán és Büttösön van helyi bolt, így számukra a nagyobb és távolabbi bevásárlás nem kényszer. A krasznokvajdaiak valamivel jobb életkörülmények között élnek, mint a többi település lakói (személygépkocsik magasabb aránya, a tömegközlekedés relatív előnyösebb helyzete), így a távolabbi boltok felkeresése is könnyebben történik meg. Ezen feltételezés még azzal is kiegészíthető, hogy a falugondnoki szolgálattal pont Büttösön és Szászfán vannak legkevésbé megelégedve a helyiek, $\mathrm{s}$ mivel ezek a nagyobb bevásárlások az apróbb falvakban (Perecse, Kány) a falugondnoki busszal történnek, megkockáztatható az a kijelentés, hogy részben emiatt sem jutnak el a távolabbi boltokba.

Szórakozni mindössze a teljes minta $24 \%$-a jár el $(\mathrm{N}=69)$. Két település került megjelölésre, Miskolc és Krasznokvajda. Az eljutás tekintetében egyharmad arányban a személygépkocsi szerepel, a helyközi autóbusz és a kombinált lehetőségek is népszerüek.

\section{A vizsgált környezet lakossági megitélése}

A térség lakóinak 70\%-a utazna munkavállalási céllal Szlovákiába, ha lenne közforgalmú kapcsolat a két állam között. Nem meglepő, hogy föként az aktív korúakkal (nagyobb arányban) rendelkezö falvak lakói mennének legszívesebben. Akik nem mennének, főként idős korukra hivatkoztak ( $36 \%$ ), de sokan egyéb kategóriát is megjelöltek (drága, elvi okok stb.), továbbá néhányan autóval mennének vagy nem munkavállalási céllal. A válaszadók $86 \%$-a nem költözne el jelenlegi lakóhelyéról. Az idös korúak esetében ez teljesen érthető, azonban az aktív korúak körében a költözést elutasítók magas aránya (84\%) már magyarázatra szorul. A válaszok megtalálhatók Kiss János Péter magyarországi aprófalvakról írt tanulmányában (Kiss 2008), miszerint e településkategóriában az aktív korú lakosok helyben való megtartó ereje igen magas, s ezek az erők végtelenül összetettek, de jobbára gazdasági és társadalmi eredetủek (egy élet munkája során felépített ház, családi és baráti kapcsolatok, utóparaszti hagyományok stb.). Aki el akar költözni - mindössze 38 személlyel találkoztak kérdezőbiztosaink -, azok körében sincs egyértelmü cél: mindössze $24 \%$-uk menne a megyeszékhelyre (föként a vajdaiak), további $18 \%$ városhoz közeli településre, 13\%-ban pedig bárhova, ahol munka van.

\section{Következtetések}

A vizsgált térség gazdasági fellendülése valószínúleg nem fog az elkövetkezendö évtizedben bekövetkezni, persze kérdéses, hogy a határok szabad átjárhatósága okán létrejövő munkaerő mozgás mennyire képes a térséget a jelenlegi helyzetéből kimozdítania. A közlekedési szokások terén azonban átrendeződések elindulásának 
lehetünk szemtanúi, mégpedig a személygépkocsi használat növekedése mellett a falugondnoki szolgálatnak a közforgalmú személyszállításban betöltött szerepe kapcsán. Jóllehet, hogy bizonyos falvakban (Szászfa, Büttös) az igencsak hiányos helyközi autóbuszos szolgáltatást veszik jobbára igénybe, azonban ennek részaránya folyamatosan csökken. A Hétközség falvaiban mủködő falugondnoki szolgálat más térségekhez képest eddig is külön figyelmet fordított a közforgalmú személyszállítás lebonyolítására, jelentősége várhatóan még jobban fel fog értékelődni azt követően, hogy a Volán társaságok teljesen kivonulnak a legkisebb törpefalvakból. Ezen változással párhuzamosan meg kell teremteni a lehetőségét annak, hogy a falugondnoki szolgálat autóbuszait a közforgalmú közlekedési rendszerbe integrálják, továbbá kapcsolódási pontokat, ill. egy ráhordó rendszert kell kialakítani a fövonalakon futó autóbuszvonalak felé.

\section{Jegyzetek}

${ }^{1}$ Természetföldrajzilag a Rakacai-völgymedencéhez (Krasznokvajda, Büttös, Pamlény, Szászfa), valamint a Keleti-Csereháthoz (Kány, Keresztéte, Perecse) sorolhatók a vizsgált települések (MarosiSomogyi 1990).

${ }^{2}$ Korábban hétvégén is volt ügyelet Krasznokvajdán, de mivel évek óta csak egy háziorvos van a faluban, ezért a szolgáltatást már nem lehetett fenntartani, így 2005-ben megszünt. Jelenleg Encsen van legközelebb hétvégi ügyelet - Bujnóczki Sándor szóbeli közlése alapján.

3 A posta napjainkban már csak szükített nyitvatartási időben mủködik, 9-11 óra között.

4 Akkoriban a 7 település közös tanács irányítása alá tartozott.

${ }^{5}$ Az egykori közös termelöszövetkezet hatása ma is jól megmutatkozik, hiszen az érintett falvak lakói között mai napig is szoros kapcsolat van a korábbi közös munkahely miatt - Vaszily Szilárd szóbeli közlése alapján.

${ }^{6}$ A ritka kivételek közé tartozott az orvosi ellátás, hiszen a krasznokvajdai orvos az idősebb lakosok elbeszélése alapján már ekkoriban is szekérrel járta a környező falvakat. Ezen kívuil vásári napokon természetesen eljutottak az itteni lakosok is Encsre.

${ }^{7}$ Kérdezőbiztosok: Babinszki Csilla, Eötvös Oszkár, Gansperger Gábor, Jablonszky Ábel, Kis István, Kondákor Ádám, Rhédey Gábor, Takács Ákos geográfus hallgatók, ELTE. A 2007. évi 311/2007. (XI. 17.) kormányrendelet szerint az Encsi kistérség a komplex programmal segítendỏ leghátrányosabb helyzetü kistérségek közé tartozik. Korábban a 2006. évi 240/2006. (XI. 30.) kormányrendelet a vizsgált települések köziil csak Krasznokvajdát és Perecsét nem sorolta a társadalmigazdasági és infrastrukturális szempontból elmaradott települések közé.

9

Az elörejelzés a 2001-2006 közötti éves növekedési uitem továbbvezetésével készült.

${ }^{10}$ Az utóbbi 2 évben több telepủlés (Gagyvendégi, Gagybátor, Rakacaszend) is Krasznokvajdára irányí totta át általános iskolás tanulóit, ennek következtében mintegy másfélszeresére nőtt a diákok száma. Így egyelöre el lehetett kerülni az alsó tagozatos osztályok összevonását.

11 A krasznokvajdai székhelyü körjegyzóséghez 4 település tartozik: Büttös, Kány, Krasznokvajda, Perecse.

${ }^{12}$ A cég tulajdonosainak Magyarországon kívül is jelentős érdekeltségei vannak, többek között a Délafrikai Köztársaságban.

13 Mivel egy családban ma már csak I fö kaphat támogatást, így ez a családok jelentős részét érinti.

14 A helyiek közül többen megemlítették, hogy a buszvezetôvel lehet egyezkedni a buszjegy áráról. Például Miskolcról indulva csak Baktakékig ad menetjegyet 450 forintért, de az utas tovább utazik Krasznokvajdára. A különbözetet (450 forint) pedig megfelezi a buszsofőr és az utas. Így anyagilag 
mind a két fél jól jár, legfeljebb a menetjegy eladások alapján készuilt statisztikákból úgy tünik, hogy alig van utas Baktakék után.

${ }^{15} \mathrm{Pl}$. reggel a Rakacáról Miskolcra tartó busz vagy a délutáni Miskolc-Perecse járat.

${ }^{16}$ Az 1988-as menetrendben ezek a bányászjáratok már nem szerepelnek.

17 A kutatás időpontjában, azaz 2008 augusztusának utolsó hetében. Az azóta eltelt idỏben a legfontosabb menetrendi változás a reggeli iskolabusz perecsei betérésének a kihagyása.

18 Ezt követően még 15.10-kor el lehet jutni ugyan a megyeszékhelyre, de csak baktakéki átszállással, ahol 40 (!) percet kell várni a csatlakozó buszra.

19 Az egyik busz Homrogdon, a másik pedig Baktakéken keresztül.

${ }^{20}$ Szászfáról Encsre csak tanítási napokon reggel van busz, míg Encsröl Szászfára ugyancsak iskolaidőben reggel, valamint délután fél egykor, amelyből a keddi, szerdai és pénteki járatok csak tanítási napokon közlekednek.

21 Ennek az egyik oka, hogy tanítási napokon a járatok betérnek a krasznokvajdai iskolához, ami a tanszünetihez képest öt perccel hosszabb menetidôt eredményez, valamint egyes járatok hétfơn és csütörtökön nem érintik Keresztétét.

22 Egy mikrobusz, egy 18 fös kisbusz és egy 6 fös platós kisteherautó.

23 A krasznokvajdai konyháról összesen 12 településre hordanak ebédet.

24 A hagyományos korfelosztást (0-18, 19-59) egyrészt azért vetettuik el ilyen formában, mivel a válaszadók 14 év felettiek voltak, másrészt pedig a 14-25 év közötti korosztály megjelölésével a fiatal felnőtteket jobban számba tudtuk venni.

25 Ahogy a kányi és a perecsei lakosok megfogalmazták: „a falugondnok olyan nekünk, mint egy falat kenyér".

\section{Irodalom}

Beluszky P. (1977) Krasznokvajda - Egy alsófokú központ gondjai a Csereháton. - Földrajzi Értesítö. 3-4. 349-386. o.

Dobány Z. (1999) A Cserehát történeti földrajza (18-20. század). BGYTF, Nyíregyháza.

Kiss J.P. (2008) Aprófalvasodás és aprófalvaink sorsa - történelmi metszetben. - Váradi M.M. (szerk.) Kistelepuilések lépéskényszerben. Ưj Mandátum Kiadó, Budapest. 29-65. o.

Kostyál Á. (2008) A magyar falugondnoki hálózat. - Kistáska. 62. 18-22. o.

Ladányi J.-Szelényi I. (2004) A kirekesztettség változó formái. Napvilág Kiadó, Budapest.

Leskó S. (2008) Belsö-Cserehát hátrányai és lehetőségei egy határ menti telepủlés tükrében. Diplomamunka. Miskolci Egyetem, Szociológiai Intézet, Miskolc.

Marosi S.-Somogyi S. (szerk.) (1990) Magyarország kistájainak katasztere I.-11. MTA FKI, Budapest. Szabó Sz. (2006) A helyközi autóbusz-közlekedés aktuális problémái. - Földrajzi Értesítő. 3-4. 321-332. o.

Szanyi É.-Kemény B. (2003) A falugondnoki és tanyagondnoki szolgáltatás rendszere Magyarországon, Szakmai útmutató. Egészségügyi, Szociális és Családügyi Minisztérium - Nemzeti Család- és Szociálpolitikai Intézet, Budapest.

Új Magyarorszâg Vidékfejlesztési Program (UMVP) (2007). Budapest. 